\title{
IS DIGITAL RECTAL EXAM RELIABLE IN GRADING ANAL SPHINCTER DEFECTS?
}

\author{
Marcelo de Melo Andrade COURA, Silvana Marques SILVA, \\ Romulo Medeiros de ALMEIDA, Miles Castedo FORREST and João Batista SOUSA
}

Received 7/7/2015

Accepted 14/8/2015

\begin{abstract}
Background - Anal sphincter tone is routinely assessed by digital rectal examination in patients with fecal incontinence, although its accuracy in detecting sphincter defects or separating competent from incompetent muscles has not been established. Objective - In this setting, we aimed to evaluate the accuracy of digital rectal examination in grading anal defects in order to separate small from extensive cases as depicted on 3D endoanal ultrasound, using a scoring sphincter defect and correlate anal tone to anal pressures. Methods - Women with fecal incontinence were divided into two groups: small or extensive defects according to the ultrasound scoring system. Sensitivity, specificity, positive and negative predictive values of digital rectal examination in grading global and external sphincter defects were calculated. Anal tone at digital rectal examination was compared to resting and incremental pressures. Results - A cohort of 76 consecutive incontinent women were enrolled. The median Wexner score was 9. Sixty-eight showed sphincter defects on 3D endoanal ultrasound. Anal tone at digital rectal examination was considered abnormal in 62 cases. Abnormal digital rectal examination showed a sensitivity of $90 \%$, specificity of $27.78 \%$ in distinguishing small from extensive defects of both sphincters. Five out of eight women with no sphincter defects had only abnormal squeeze tone at digital rectal examination. Abnormal squeeze tone at digital rectal examination had a sensitivity of $65.31 \%$ in distinguishing small from extensive external anal sphincter defects. Digital rectal examination sensitivity increased linearly from small to extensive external anal sphincter defects $(P=0.001)$. Women with abnormal resting tone had lower resting pressures than women with normal tone at digital rectal examination $(P=0.0001)$. Women with abnormal squeeze tone had lower incremental pressures than women with normal tone at digital rectal examination $(P=0.017)$. Conclusion - Digital rectal examination had good sensitivity and poor specificity in discerning small from severe global anal sphincter defects. Moreover, digital rectal examination had fair sensitivity and poor specificity in grading external anal sphincter defects, and its best accuracy was on complete external anal sphincter lesions. Anal resting and squeeze tone were correlated to anal pressures.
\end{abstract}

HEADINGS - Digital rectal examination. Fecal incontinence. Ultrasonography. Manometry. Anal canal, physiology.

\section{INTRODUCTION}

Fecal incontinence (FI) is a symptom that affects patients' quality of life. Surveys have reported a FI prevalence of up to $12 \%{ }^{(6)}$. Continence depends on consistency of fecal matter, neuromuscular sphincter complex entirety, rectal capacity, sensation and ability to freely move and reach a toilet ${ }^{(19)}$.

Obstetric anal sphincter injuries (OASIS) is believed to be the most important cause of FI, and as many as $44 \%$ of women with OASIS will develop FI later in life $\mathrm{e}^{(22,26)}$

Conversely, about $75 \%$ of incontinent patients have sphincter lesions on endoanal RNM or ultrasound ${ }^{(8,16,23)}$. These cases must be identified in order to define the best form of treatment ${ }^{(28)}$.

Digital rectal examination (DRE) is routinely performed in clinical practice, among other reasons to assess anal sphincter tone, especially in fecal incontinent patients ${ }^{(9)}$. Although DRE is an important part of diagnostic work-up, its value in predicting unsuspected sphincter lesions or discerning functionally normal from abnormal anal muscles has not yet been proven ${ }^{(7,9,14)}$.

Eckardt et al. examined 64 fecal incontinent women and found a poor sensitivity and specificity of DRE for diagnosing incompetent anal sphincters.

Dobben et al. found that anal tone at DRE was correlated to resting and squeeze pressures, and that its positive predictive value was higher in more extensive external anal sphincter (EAS) lesions ${ }^{(7)}$.

However, Jeppson et al. found that DRE has a poor sensitivity in detecting sphincter defects regardless of the grade of EAS disruption ${ }^{(14)}$.

To date, no study has compared DRE accuracy in grading anal sphincter defects depicted on $3 \mathrm{D}$ endoanal ultrasound (EAUS) using a specific scoring system. Thus, the aims of this study were to evaluate DRE capacity in predicting severity of anal sphincter defects and correlate DRE findings to resting and incremental anal pressures, in fecal incontinent women with a high prevalence of anal sphincter defects.

Faculdade de Medicina Universidade de Brasília, Brasília Distrito Federal, Brasil. 


\section{METHODS}

This study was carried out in a specialized colorectal clinic. The clinical protocol was submitted to the Faculty of Medicine Research Ethics Committee of the University of Brasilia and to the Research Ethics National Committee, and was approved on 10/01/2014 as number 18769413.5.0000.0030.

\section{Patients}

Between February 2014 and May 2015, consecutive female patients with symptoms of FI were enrolled, mostly from public hospitals.

FI was defined as follows: any involuntary loss of flatus/fecal content or inability to defer an evacuation to a proper moment, with at least one monthly episode, in the last 3 months $^{(1,5)}$.

Patients less than 18 years-old, with dementia, neurologic or medular disorders, chronic diarrhoea, inflammatory bowel disease, colorectal cancer, multiple sclerosis, sclerodermia, previous colorectal surgery, ileal pouch or submitted to a biofeedback in the last 6 months were excluded.

All patients signed a consent form, filled out a general and obstetric questionnaire and a Wexner Score for grading $\mathrm{FI}^{(15)}$. Afterwards, they underwent anorectal manometry, DRE and 3D EAUS in a one-stop visit.

The same examiner performed all manometry evaluations (SMS).

Digital rectal examination and ultrasounds were all performed by the main researcher (MMAC) experienced in 3D EAUS. Both examiners were blind to each other's results.

\section{Anorectal manometry}

A water-perfused flexible catheter connected to an 8-channel manometer (Dynamed, Procto Master Software, São Paulo, Brazil) was used. Mean resting and mean squeeze pressures were measured at high-pressure zones. High-pressure zones were defined as the part of the anal canal where pressures were $50 \%$ higher than rectal pressures ${ }^{(13)}$. Exams were performed by a pull-through technique where measures were obtained at each centimeter in the high-pressure zone.

Squeeze pressures were obtained by asking patients to squeeze for $10 \mathrm{~s}^{(4,9)}$. A manometer catheter generates eight different measurements at each centimeter and the software calculated a general mean for resting and squeeze.

Pressures $<40 \mathrm{mmHg}$ were considered as low resting pressures and $<60 \mathrm{mmHg}$ as low incremental pressures ${ }^{(4,10)}$.

Incremental pressures were defined as the difference between squeeze and resting pressures ${ }^{(10,12)}$.

\section{Digital rectal examination and 3-d endoanal ultrasound}

Patients were placed in the left lateral decubitus with no previous rectal enema and underwent DRE immediately before 3D EAUS. Digital rectal examination was performed by introducing a lubricated gloved index finger into the anal canal and lower rectum to assess sphincter tone at rest and under voluntary contraction.
Anal resting and squeeze tone were recorded separately and rated as normal: when anal tone perceived by the examiner was similar to that of a normal patient; absent: when no muscular activity was perceived by the examiner; or diminished: when there was any degree of muscular activity between these two ${ }^{(7)}$. Note that the examiner is an experienced colorectal surgeon who assesses anal tone from continent and incontinent patients on a daily basis.

3D EAUS was performed by using an endoanal probe Pro-Focus 2052, 9-16 MHz, 360 $0^{\circ}$, focal distance up to 6.2 cm (B\&K Medical, Herlev, Denmark).

The endoanal probe was introduced up to $6 \mathrm{~cm}$ or until the upper part of puborectalis muscle was clearly visualized. The signal captured forms 3D images as two crystals move along a longitudinal axis producing multiple biplanar slices that are assembled to create high-resolution volumetric $3 \mathrm{D}$ cubes.

External and internal anal sphincter (IAS) defects were analyzed on multiple planes ${ }^{(24)}$.

An EAS defect was defined as any disruption of its hyperechoic ring associated with irregular borders of disrupted muscle and an IAS defect was defined as any disruption of its hypoechoic ring at any level in the anal canal ${ }^{(12)}$ (Figure 1).

Defects were graded by using a scoring system. This score takes into account the longitudinal and radial grade of EAS and IAS defects, separately ${ }^{(21)}$ (Table 1).

Anal sphincter defects were rated as mild or severe when the total score was respectively $<4$ or $>=4$, respectively. In order to analize sensitivity for different grades of external anal sphincter, defects were further rated as mild (score $=0-2$ ), moderate $($ score $=3)$, and severe $(\text { score }=4)^{(21)}$.

Women with normal or abnormal DRE were compared as to grade of sphincter defect and grade of EAS defect on 3D EAUS by using a specific scoring system.

Normal v/s abnormal resting and squeeze tones at DRE were correlated to resting and incremental pressures.

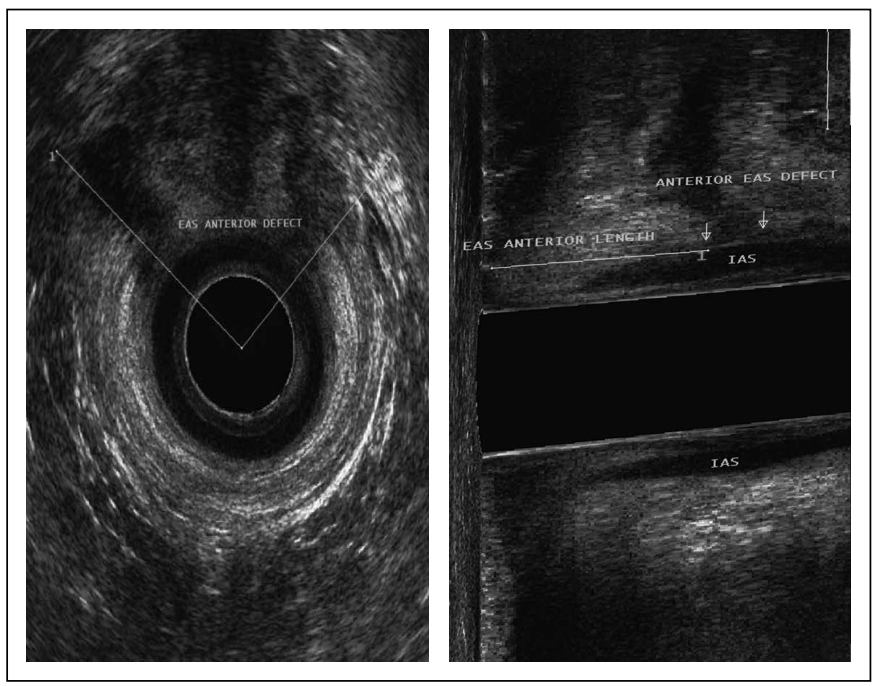

FIGURE1. Left: Anterior external anal sphincter angle defect (axial plane); right: external anal sphincter longitudinal length and defect (sagittal axis) on $3 \mathrm{D}$ endoanal ultrasound. 
TABLE 1. Scoring system to graduate external and internal anal sphincters. Individual values of each sphincter are calculated and added to obtain a total score

\begin{tabular}{|c|c|c|c|c|}
\hline $\begin{array}{l}\text { EAS } \\
\text { Defect score }\end{array}$ & 0 & 1 & 2 & 3 \\
\hline $\begin{array}{l}\text { Longitudinal } \\
\text { extension }\end{array}$ & $\leq 50 \%$ & $>50 \%$ & - & - \\
\hline Depth & No defect & Parcial $(\geq 50 \%)$ & Total $\leq 90$ & Total $>90$ \\
\hline $\begin{array}{l}\text { IAS } \\
\text { Defect score }\end{array}$ & 0 & 1 & 2 & \\
\hline $\begin{array}{l}\text { Longitudinal } \\
\text { extension }\end{array}$ & $\leq 50 \%$ & $>50 \%$ & - & \\
\hline Depth & No defect & No defect & Total $>90$ & \\
\hline
\end{tabular}

\section{Statistical analysis}

The reported prevalence of sphincter defects in women with FI varies from $31 \%$ to $87 \%{ }^{88,16,22)}$.

It was assumed that about $75 \%$ of patients would have a defect on EAUS since most elected cases had not responded to clinical or biofeedback treatments, hence with a high chance of having a defect.

Sampling calculations carried out with confidence interval (CI) set at $95 \%$ and type II error set at $20 \%$ established that 73 patients would suffice for our study.

Continuous data were expressed as mean, median and standard deviation (SD).

Cases in which the tone was scored as diminished or absent were grouped together and labeled as abnormal DRE.

In order to assess the accuracy of DRE in detecting anal sphincter defect severity and EAS defects on 3D EAUS, sensitivity, specificity, and positive and negative predictive values were calculated by using contingency tables.

Difference between anal resting and incremental pressures in patients with normal and abnormal tone was calculated by means of the Fisher's exact test and $\chi^{2}$ test.

$P<0.05$ was considered statistically significant.

We used the SPSS 21 (Special Package for Social Sciences) for Windows software for all of the analyses.

\section{RESULTS}

\section{Patient characteristics}

Seventy-six $(92.59 \%)$ of the 82 women enrolled completed all steps. Six patients were excluded: four refused to fill out the clinical protocol, and two had had biofeedback sessions during the previous month. The mean age was 56.33 (SD 14.62). Thirty-nine $(51.31 \%)$ had associated urinary incontinence.

Sixty-four $(84.21 \%)$ had at least one vaginal delivery (median 2; range 1-20), 53 (82.81\%) reported an episiotomy. Four $(5.26 \%)$ women only had cesarean sections and eight $(10.53 \%)$ were nulliparous.

The mean Wexner Score was 9.16 (CI: 8.11-10.21).

Mean resting pressures were $36.05 \mathrm{mmHg}$ (SD 19.30) and incremental pressures were $50.21 \mathrm{mmHg}$ (SD 34.89).

Sixty-two (81.58\%) women were scored as having abnormal anal tone at DRE. Fifty $(65.79 \%)$ women had abnormal anal resting tones and $47(61.84 \%)$ had abnormal squeeze anal tones at DRE.

\section{Three-dimensional endoanal ultrasound}

Sixty-eight $(89.47 \%)$ women had a sphincter defect on EAUS. Forty-six (67.64\%) had combined EAS and IAS defects, $21(30.88 \%)$ only had EAS defect, and $1(1.48 \%)$ case only had IAS defect.

Median ultrasound score was 4 (range 1-7). Forty $(52.63 \%)$ had severe defects (score $>=4$ ).

Sixty-seven $(88.16 \%)$ women had combined or isolated EAS defect, $49(73.13 \%)$ of which extensive defect.

\section{Global sphincter defect and anal tone at DRE}

Thirty-six out of 62 patients with anal tone scored as abnormal had extensive sphincter defect, whereas only 4 out of 14 with normal anal tone had extensive sphincter defect. Evaluation of anal sphincter tone at DRE showed sensitivity of $90 \%(95 \%$ CI $76.34 \%$ to $97.21 \%)$, specificity of $27.78 \%(95 \%$ CI $14.20 \%$ to $45.19 \%$ ), positive predictive value (PPV) of $58.06 \%$ ( $95 \%$ CI $44.85 \%$ to $70.49 \%$ ), negative predictive value of $71.43 \%$ $(95 \%$ CI $41.90 \%$ to $91.61 \%)$ and accuracy of $60 \%$ in separating mild from severe anal defects for both sphincters. Table 2.

Five $(62.5 \%)$ out of 8 patients with no defect on 3D EAUS had an abnormal tone at DRE, all of them with abnormal squeeze tone and normal anal resting tone.

TABLE 2. Findings at DRE and global anal sphincter defects scores on 3D EAUS

\begin{tabular}{lccc}
\hline $\begin{array}{l}\text { DRE vs grade defect on } \\
\text { EAUS (score) }\end{array}$ & $\begin{array}{c}\text { Abnormal } \\
\text { DRE }\end{array}$ & Normal DRE & Total \\
\hline Mild defect (0-3) & 26 & 10 & 36 \\
Extensive defect (4-7) & 36 & 4 & 40 \\
Total & 62 & 14 & 76 \\
\hline DRE: digital rectal examination; EAUS: endoanal ultrasound.
\end{tabular}

\section{External anal sphincter defect scores and squeeze tone at DRE}

Thirty-two out of 47 women with abnormal squeeze tone had EAS extensive defect on EAUS, while 17 out of 29 with normal squeeze tone had EAS extensive defect. Evaluation of anal squeeze tone at DRE showed sensitivity of $65.31 \%(95 \% \mathrm{CI} 50.36 \%$ to $78.33 \%)$, specificity of $44,44 \%$ (95\% CI $25.48 \%$ to $64.67 \%$ ), positive predictive value (PPV) of $68.09 \%$ (95\% CI $52.88 \%$ to $80.91 \%$ ), negative predictive value of $41.38 \%$ (95\% CI $23.52 \%$ to $61.06 \%$ ) and accuracy of $57.89 \%$ in separating small from extensive EAS defects. Table 3.

TABLE 3. Anal squeeze tone at DRE and severity of EAS sphincter defect on 3D EAUS

\begin{tabular}{lccc}
\hline $\begin{array}{l}\text { Squeeze tone at DRE vs EAS } \\
\text { defect grade on EAUS (score) }\end{array}$ & $\begin{array}{c}\text { Abnormal } \\
\text { squeeze tone }\end{array}$ & $\begin{array}{c}\text { Normal } \\
\text { squeeze tone }\end{array}$ & Total \\
\hline Small EAS defect (0-2) & 15 & 12 & 27 \\
Extensive EAS defect (3-4) & 32 & 17 & 49 \\
Total & 47 & 29 & 76 \\
\hline DRE: digital rectal examination; EAS: external anal sphincter; EAUS: endoanal ultrasound.
\end{tabular}


When sensitivity of DRE was calculated regarding different EAS defect scores, DRE effectiveness in identifying anal defects displayed a linear increase, with the highest sensitivity for more severe EAS lesions. Thirteen out of 26 patients with small defects (scores $0-2$ ) had abnormal squeeze tone at DRE ( $50 \%$ true positive). This rate rose to $63.5 \%$ (24 out of 38 had abnormal DRE) in moderated EAS defects (score $=3$ ) and $83.33 \%$ (10 out of $12 \mathrm{had}$ abnormal DRE) in cases with complete radial and longitudinal disruption of the external anal sphincter (maximum score of 4$)\left(P=0.001, \chi^{2}\right.$ test).

\section{Digital rectal examination tone and anal pressures}

Patients with abnormal resting tone had mean resting pressures significant lower than patients with normal resting tone $(29.31 \mathrm{mmHg}$; SD 15.69 vs $49.04 \mathrm{mmHg}$; SD 19.21) $(P=0.0001)$ (Figure 2).

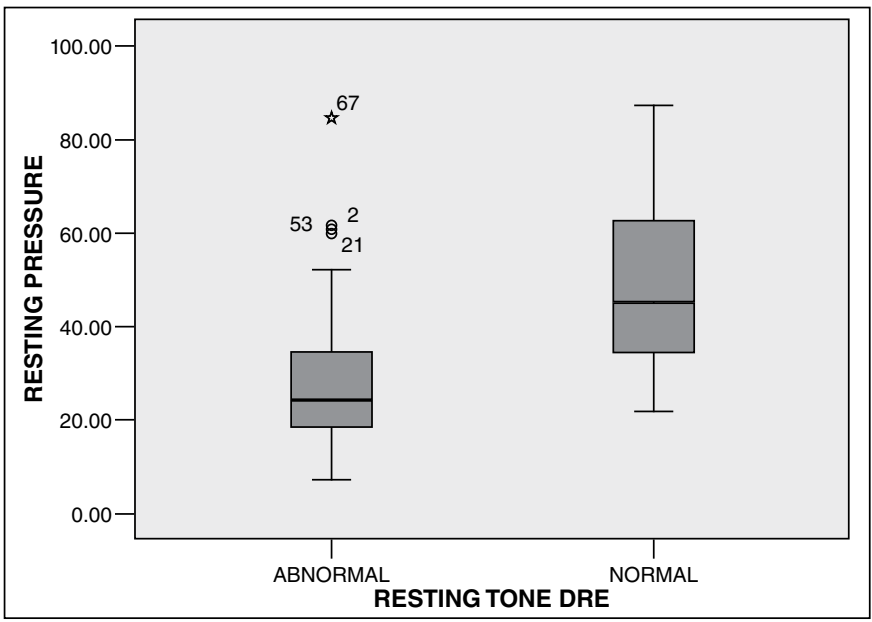

FIGURE 2. Comparison of resting pressures between cases with normal and abnormal anal resting tone at digital rectal examination $(P=0.0001)$

Patients with abnormal squeeze tone had mean incremental pressures significantly lower than patients with normal squeeze tone $(44.36 \mathrm{mmHg}$; $\mathrm{SD} 33.92$ vs $59.70 \mathrm{mmHg}$; SD 39.94) $(P=0.017)$ (Figure 3$)$.

\section{DISCUSSION}

Digital rectal examination (DRE) is part of routine diagnostic work-up in patients with fecal incontinence, mainly in order to assess anal tone and occasionally find an unsuspected anal sphincter defect ${ }^{(27)}$. Since incontinent patients, specially women, have a higher prevalence of sphincter defects, DRE is believed to be a reliable tool in this setting. Nonetheless, studies addressing its value in predicting anal sphincter defects have shown conflicting results ${ }^{(8,9,14,25)}$ and no consistent correlation between anal tone and anal pressure has been established ${ }^{(3,9,17,29)}$.

In order to enhance DRE accuracy, we aimed to investigate its role by studying a cohort with a high prevalence of sphincter defects and compared anal tone to grade of anatomical defects on 3D EAUS, using a specific scoring system.

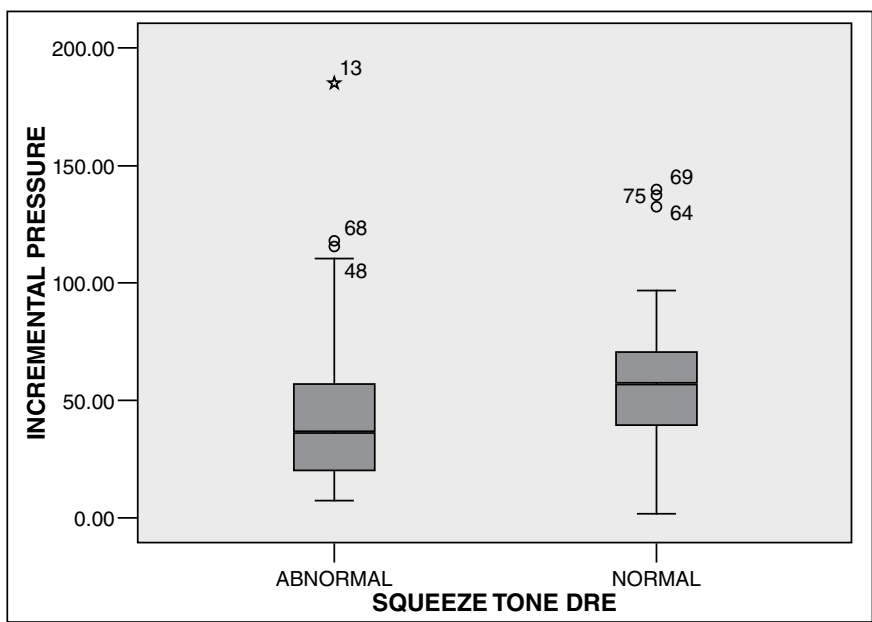

FIGURE 3. Comparison of incremental pressures between cases with normal and abnormal anal squeeze tone at digital rectal examination $(P=0.0001)$

It was found that digital rectal examination showed good sensibility in detecting extensive defects of the whole anal canal but an only a fair sensibility in detecting EAS defects, although sensitivity of DRE in correctly finding EAS defects increased as EAS scores worsened. Anal resting and incremental pressures correlated to some extent with resting and squeeze tone.

It is not surprising that DRE tone was abnormal in over $80 \%$ of the cases, as almost $90 \%$ of fecal incontinent women had a sphincter defect on EAUS. In fact, having an abnormal DRE gives $90 \%$ certainty of detecting a severe defect in both muscles. In spite of this, DRE was rated as abnormal in five out of eight cases with no sphincter defects (false positive $62.5 \%$ ). Although the sample size is too small to draw definitive conclusions, it is noteworthy that even in a setting with a high prevalence of sphincter defects DRE had such a poor specificity.

Some authors have found similar results in samples with

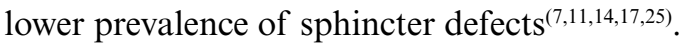

Moreover, almost $40 \%$ of patients presenting an abnormal DRE had small sphincter defects and one third with normal tone at DRE had extensive defects.

\section{Many factors could explain this discrepancy}

First, it is believed that the examiner's experience could interfere in DRE accuracy ${ }^{(7,9,25,29)}$.

The examiner who performed all DRE and ultrasounds in this study has performed over 8,000 examinations in his routine practice dedicated to evaluating continent and incontinent patients. Even so, DRE tone appeared as having a highly subjective interpretation. Normal tone at DRE perceived by the examiner (defined as the tone that a normal patient would have) did not consistently reflect a competent and intact muscle ${ }^{(7,11)}$.

More than one examiner evaluating anal tone could have reduced subjective interpretations $s^{(3,7,17,25)}$. Nonetheless, it is doubtful that our findings would have been very different, 
since examiner misinterpretation tends to occur as a result of factors such as sphincter arrangement, rather than to variation from one examiner to another ${ }^{(14,20)}$.

Second, regardless of inherent subjectivity, normal anal resting and squeeze tone do not necessarily reflect an intact IAS or EAS ${ }^{(11,17)}$. Resting tone and pressures are influenced by EAS tone. Thus, even a severe defect of the IAS may have been compensated by a competent EAS, leading to perception of a normal resting tone at $\mathrm{DRE}^{(11)}$. Similarly, an intact puborectalis muscle may generate normal squeeze tone and pressures, overcoming an extensive EAS defect, not to mention that squeeze tone depends on how well patients are capable of coordinating their voluntary sphincters and this varies greatly ${ }^{(11,14,20)}$.

Some would argue that performing DRE before EAUS by the same examiner in an unblinded fashion could have introduced a bias toward identifying more severe lesions, therefore enhancing DRE accuracy ${ }^{(14)}$. This does not seem to be the case, as only $58 \%$ patients with abnormal DRE had severe defects on EAUS.

Curiously, all cases with no defects and abnormal anal tone had normal resting tone but reduced or absent squeeze tone. In order to explain this, EAS defects were analyzed. DRE was no better in separating severe EAS defects than it had been in separating overall severe sphincter defects.

Squeeze tone at DRE had poor sensitivity and specificity in detecting severe EAS lesions. Nonetheless, when EAS defects were further divided into three groups (small, intermediate and severe lesions), sensitivity increased to $85 \%$ in detecting severe defects. That is say, one-half of cases with small defects had normal squeeze tone, whereas less than $15 \%$ with extensive EAS had normal examination results.

EAS has an irregular shape with a natural anterior defect in the middle anal canal, even in nulliparous continent women ${ }^{(2)}$. This could explain why DRE sensitivity was better at detecting more extensive cases, in which the anterior disruption usually affected the whole length of the EAS, posing no doubt to the examiner ${ }^{(7,14)}$.

Dobben et al. observed that sensitivity of anal squeeze tone at DRE was better for severe defects than for small ones, although they have shown poor sensitivity in finding EAS defects. The same authors found some correlation between anal resting and squeeze tone to resting and incremental pressures ${ }^{(7)}$.

Conversely, other studies have shown that DRE tone was either not related or related only to squeeze pressures ${ }^{(3,9,18,25)}$.

In this study, despite its inaccuracy in assessing anatomical defects, DRE tone was correlated to sphincter function, since women with abnormal resting tone had lower resting pressures whereas women with abnormal squeeze tone also had lower incremental anal pressures than those with normal DRE.
It is a remarkable finding that DRE led to the diagnosis of functional impairment, even in this setting of incontinent patients who have lower resting and incremental pressures than continent ones ${ }^{(4,10)}$. It represents a very important point in diagnostic work-up, as DRE could enable surgeons to predict which patients might benefit from sphincteroplasty.

\section{This study has some limitations}

As only eight cases showed no defects, maybe a larger sample could have led to different conclusions. Sample power calculation had suggested that 73 cases would be sufficient taking into account a sphincter defect prevalence of $75 \%$. Moreover, we aimed to study cases where sphincter defects were more likely and even in this sample DRE had fair accuracy and poor specificity, regardless of having been performed by an experienced colorectal surgeon.

Adding more examiners blinded to one anothers' results might have mitigated the dependency on only one interpretation. As stated, most studies that included more than one examiner have been in accordance with our findings ${ }^{(3,7,14,17,18,25)}$.

\section{This study has two main strengths}

First, to our knowledge this is the first prospective, blinded study evaluating DRE accuracy by using a specific scoring system on 3D EAUS and anorectal manometry, in women with sphincter defects from many causes.

Second, the sample had a high prevalence of sphincter defects, which represents well the prevalence expected in incontinent patients, as opposed to the samples of incontinent patients in previous studies, whose prevalence of defects was lower than $50 \%$ of that to be expected in FI women ${ }^{(8,16,23)}$.

\section{CONCLUSION}

In this study, it was demonstrated that anal resting and squeeze tone assessed by DRE had a poor correlation with grade of sphincter defects. Instead, DRE sensitivity was better for more severe EAS defects. Anal tones were found to correlate with, but not perfectly match, anal pressures.

Therefore, it is strongly recommended to perform a comprehensive diagnostic work-up in fecal incontinent patients by using DRE along with anorectal manometry and 3D EAUS, in order to find sphincter defects amenable to surgical repair. Despite, DRE remains indispensable at each clinical evaluation.

\section{Authors' contributions}

Coura MMA: main researcher, data collection, survey execution, statistical analysis, writing of text. Silva SM: data collection, survey execution, writing of text. Almeida RM: data collection, survey execution, writing of text. Forrest MC: writing of text. Sousa JB: statistical analysis, writing of text. 
Coura MMA, Silva SM, Almeida RM, Forrest MC, Sousa JB. O toque retal é confiável em graduar defeito dos esfíncteres anais? Arq Gastroenterol. 2016,53(4):240-5.

RESUMO - Contexto - O toque retal é exame clínico rotineiro na avaliação coloproctológica, especialmente em pacientes com incontinência fecal. Entretanto, sua acurácia é variável na predição de defeito esfincteriano ou de alterações nas pressões anais. Objetivo - Avaliar a sensibilidade, especificidade, valores preditivo positivo e negativo da avaliação do tônus esfincteriano ao toque retal, em diferenciar defeitos leves de defeitos graves em mulheres com incontinência fecal e correlacionar tônus com pressões anais. Métodos - Mulheres portadoras de incontinência fecal e estratificadas de acordo com o grau de defeito ao ultrassom endoanal tridimensional (USEA 3D) foram avaliadas com toque retal e manometria anorretal. O tônus esfincteriano ao toque retal foi comparado com o grau de defeito e com as pressões anais no repouso e na contração. Resultados - Das 76 mulheres com sintomas de incontinência fecal, 68 tinham defeito esfincteriano ao USEA 3D. Quarenta pacientes com defeitos graves. Escore de Wexner mediano de 9 . O tônus esfincteriano ao toque retal foi considerado alterado em 62 casos. Um toque retal alterado teve alta sensibilidade e baixa especificidade em distinguir defeitos esfincterianos leves de extensos. Das oito pacientes sem defeito muscular, cinco tinham tônus ao toque retal alterado sendo todas no tônus na contração. O toque retal na contração teve moderada sensibilidade e baixa especificidade em distinguir defeitos leves de esfíncter externo do ânus de defeitos extensos. A sensibilidade do toque retal na contração foi melhor quanto mais extensos eram os defeitos de esfíncter externo do ânus $(P=0,001)$. Mulheres com tônus de repouso alterado tinham menores pressões de repouso que aquelas com tônus normal $(P=0,0001)$. Mulheres com tônus de contração alterado tinham menor incremento pressórico que aquelas com tônus normal $(P=0,017)$. Conclusão - $\mathrm{O}$ toque retal possui boa sensibilidade e baixa especificidade em diferenciar defeitos leves de extensos da musculatura esfincteriana e moderada sensibilidade em diferenciar defeitos de esfíncter externo do ânus, com melhora da sensibilidade quanto mais extensos eram os defeitos de esfíncter externo do ânus. Houve correlação entre tônus e pressões anais no repouso e na contração.

DESCRITORES - Exame retal digital. Incontinência fecal. Ultrassonografia. Manometria. Canal anal, fisiologia.

\section{REFERENCES}

1. Bharucha AE, Wald A, Enck P, Rao S. Functional Anorectal Disorders. Gastroenterology. 2006;130:1510-8

2. Bollard RC, Gardiner A, Lindow S, Phillips K, Duthie GS. Normal female anal sphincter: difficulties in interpretation explained. Dis Colon Rectum. 2002;45:171-5.

3. Buch E, Alos R, Solana A, Roig JV, Fernandez C, Diaz F. Can digital examination substitute anorectal manometry for the evaluation of canal anal pressures ? Rev Esp Enferm Dig. 1998;90:90-3.

4. Chaliha C, Sultan A, Emmanuele K. Normal ranges for anorectal manometry and sensation in women of reproductive age. Colorectal Dis. 2007;10:1-6.

5. Deutekom M, Dobben AC, Terra MP, Engel AF, Stoker J, Bossuyt PMM, Boeckxstaens GEE. Clinical presentation of fecal incontinence and anorectal function: what is the relationship? Am J Gastroenterol. 2007;102:351-61.

6. Ditah I, Devaki P, Luma HN, Ditah C, Njei B, Jaiyeoba C, et al. Prevalence, Trends, and Risk Factors for fecal incontinence in United States Adults, 2005-2010.Clin Gastroenterol Hepatol. 2014;12:636-43.e2.

7. Dobben AC, Terra MP, Deutekom M, Gerhards MF, Bijnen AB, Felt-Bersma RJF, et al. Anal inspection and digital rectal examination compared to anorectal physiology tests and endoanal ultrasonography in evaluating fecal incontinence. Int J Colorectal Dis. 2007;22:783-90.

8. Dobben AC, Terra MP, Slors JFM, Deutekom M, Gerhards MF, Beets-Tan RGH, et al. External anal sphincter defects in patients with fecal incontinence: a comparison of endoanal MR imaging and endoanal US. Radiology. 2007;242:463-71.

9. Eckardt VF, Kanzler G. How reliable is digital examination for the evaluation of anal sphincter tone? Int J Colorectal Dis. 1993;8:95-7.

10. Felt-Bersma RJF, Klinkenberg-Knol EC, Meuwissen SGM. Anorectal function investigations in incontinent and continent patients-differences and discriminatory value. Dis Colon rectum. 1990;33:479-86.

11. Fernández-Fraga X, Azpiroz F, Malagelada JR. Significance of pelvic floor muscles in anal incontinence. Gastroenterology. 2002;123:1441-50.

12. Gold DM, Bartram CI, Halligan S, Humphries KN, Kamm MA, Kmiot WA Three-dimensional endoanal sonography in assessing anal canal injury. Br J Surg. 1999;86:365-70.

13. Gurland B, Hull T. Transrectal ultrasound, manometry, and pudendal nerve terminal latency studies in the evaluation of sphincter injuries. Clin Colon Rectal Surg. 2008;21:157-66.

14. Jeppson PC, Paraiso MFR, Jelovsek JE, Barber MD. Accuracy of the digital ana examination in women with fecal incontinence. Int Urogynecol J. 2012;23:765-8.

15. Jorge JMN, Wexner SD. Etiology and management of fecal incontinence. Dis Colon Rectum. 1993;36:77-97
16. Karoui S, Savoye-Collet C, Koning E, Leroi AM, Dennis P. Prevalence of anal sphincter defects revealed by sonography in 355 incontinents patients and 115 continent patients. AJR Am J Roentgenol. 1999;173:389-92.

17. Kaushal JN, Goldner F. Validation of the digital rectal examination as an estimate of anal sphincter squeeze pressure. Am J Gastroenterol. 1991;6:886-7.

18. Keating JP, Stewart PJ, Eyers AA, Warner D, Bokey EL. Are special investigations of value in the management of patients with fecal incontinence? Dis Colon Rectum. 1997;40:896-901.

19. Landenfeld CS, Bowers BJ, Feld AD, Hartmann KE, Hoffman E, Ingber MJ, et al. National Institutes of Health State-of-the-Science Conference Statement: Prevention of fecal and Urinary Incontinece in adults. Ann Int Med. 2008;148:449-58.

20. Liu J, Guaderrama N, Nager CW, Pretorius Dh, Master S, Mittal RK. Functional correlates of anal canal anatomy: puborectalis muscle and anal canal pressures. Am J Gastroenterol. 2006;101:1092-7.

21. Norderval S, Markskog A, Rossaak K, Vonen B. Correlation between anal sphincter defects and anal incontinence following obstetric sphincter tears: assessment using scoring systems for sonographic classification of defects. Ultrasound Obstet Gynecol. 2008;31:78-84

22. Oberwalder M, Connor J, Wexner SD. Meta-analysis to determine the incidence of obstetric anal sphincter damage. Br J Surg. 2003;90:1333-7.

23. Oberwalder M, Dinnewitzer A, Baig MK, Thaler K, Cotman K, Nogueras JJ, et al. The association between late-onset fecal incontinence and obstetric ana sphincter defects. Arch Surg. 2004;139:429-32.

24. Regadas FSP, Murad-Regadas SM, Lima DMR, Silva FR, Barreto RGL, Souza MHLP, Regadas Filho FSP. Anal canal anatomy showed by three-dimensional anorectal ultrasonography. Surg Endoscopy. 2007;21:2207-11.

25. Romano G, Rotondano G, Esposito P, Pellecchia L, Novi A. external anal sphincter defects: correlation between preoperative anal endosonography and intraoperative findings. Br J Surg. 1996;69:6-9.

26. Sultan AH, Kamm MA, Hudson CN, Thomas JM, Bartram CI. Anal-sphincter disruption during vaginal delivery. N Eng J Med. 1993;329:1905-11.

27. Sultan AH, Kamm MA, Talbot IC, Nicholls RJ, Bartram CI. Anal endosonography for identifying external sphincter defects confirmed histologically. Br J Surg. 1994;81:463-5.

28. Thekkinkattil DK, Lim M, Stojkovic SG, Finan PJ, Sgara PM, Burke D.A classification system for faecal incontinence based on anorectal investigations. Br J Surg. 2008;95:222-8.

29. Wexner SD, Jorge JMN. Colorectal physiological tests: use or abuse of technology? Eur J Surg. 1994;160:167-74. 